\title{
Some Links of the Pathogenesis of Endogenous Intoxication in the Mother's Organism with ABO Immunization
}

\author{
Chorieva Gulchekhra* and Mamadalieva Umida \\ Department of Obstetrics and Gynecology, Tashkent Medical Academy, Uzbekistan \\ *Corresponding author: Chorieva Gulchekhra, Department of Obstetrics and gynecology, Tashkent Medical Academy, Uzbekistan. \\ To Cite This Article: Chorieva Gulchekhra. Some Links of the Pathogenesis of Endogenous Intoxication in the Mother's Organism with ABO \\ Immunization. Am J Biomed Sci \& Res. 2019 - 5(5). AJBSR.MS.ID.000945. DOI: 10.34297/AJBSR.2019.05.000945.
}

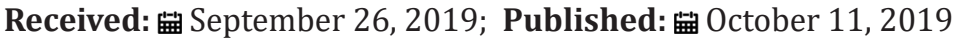

\section{Introduction}

According to foreign researchers, hemolytic disease takes the 2nd place among the causes of stillbirth, and hemolytic disease of the newborn is diagnosed in $0.5 \%$ of newborns [1]. Pregnant women with isoimmunization develop endogenous intoxication syndrome, which contributes to the development of placental dysfunction, determines the high frequency of pregnancy complications, morbidity and mortality from hemolytic disease of the newborn in newborns [2].

Recent studies have shown that in the blood of pregnant women with immunization there is an increase in the blood content of pregnant women with biologically active substances (toxic metabolites), impaired function of the biotransformation organs and, as a result, the development of endogenous intoxication syndrome at all levels of the mother-placenta-fetus system. Toxic metabolites (biological active substances), in turn, are one of the activators of the immune system, and precede the biosynthesis of antibodies [3].

Accumulating toxic metabolites that penetrate well through the placental barrier are able to have a direct toxic effect on the fetus. The study of the characteristics of metabolism in a physiologically developing placenta gives an idea of the ways of coordinating metabolic processes in the functional system mother - placenta fetus [4].

In pathological pregnancy, the immunological barrier function of the placenta is disrupted and its throughput for immunocompetent cells increases. In this regard, the developing fetus may be attacked by alloimmune antibodies of various specificities $[2,5]$.

Important indicators of endogenous intoxication are the accumulation of proteolysis products in the body that violate the system of hemocoagulation, microcirculation and the development of hypoxia, metabolic processes are disrupted, which leads to the development of destructive changes. This is of interest in conducting studies to determine the possible cause of the development of isoimmunization in women with $\mathrm{O}$ (I) Rh (+) blood type, taking into account the increased content of toxic metabolites, which in recent years include tyrosine- and tryptophan-containing peptides (TZP, TRP), molecules medium weight (MMM254, MMM280), cytochrome $\mathrm{C}$.

In 65 pregnant women with $\mathrm{ABO}$ immunization and 30 women without immunization in order to elucidate some links in the pathogenesis of endogenous intoxication in the mother's body with $\mathrm{ABO}$ immunization, we analyzed indicators of endogenous intoxication in the period of 16-37 weeks. Determination of the status of TZP, TRP, MMM254, MMM 280 and cytochrome C in the blood serum and urine of pregnant women with $\mathrm{ABO}$ immunization and in the umbilical cord blood of newborns showed significant deviations of the indicators compared with the group of healthy women.

Analysis of the results of the study showed that during ABO immunization there is a significant increase in the activity of proteolysis processes. In maternal blood serum, the level of TZP exceeds the control data by $39.3 \%$ ( $\mathrm{P}<0.001)$, TRP - by $23.1 \%$ ( $\mathrm{P}$ $<0.01$ ), MMM254 and MMM280 - by $47.1 \%$ and $22.3 \%$ (P < 0.001 and $\mathrm{P}<0.05$ ), respectively. At the same time, the serum content of pregnant women with $\mathrm{ABO}$ immunization with cytochrome $\mathrm{C}$ was increased by $28.1 \%(\mathrm{P}<0.01)$.

When analyzing the products of proteolysis in urine, their increase was also revealed. The content of TZP in the urine obtained from pregnant women with $\mathrm{ABO}$ immunization exceeded 
the control data - by $22.7 \%$ ( $\mathrm{P}<0.05)$, TRP - by $18.1 \%(\mathrm{P}<0.05)$, MMM254 and MMM280 - by $56.8 \%$ and 20.0\% ( $<<0.001$ and $\mathrm{P}$ $<0.05)$.

It should be emphasized that there is a unidirectional dynamic of increasing TZP, TRP, MMM254, MMM280 and cytochrome C in the blood and urine of the mother. This largely testifies to a single mechanism for the development of endogenous intoxication, membrane pathology during immunological incompatibility of maternal and fetal blood, which possibly determines the high frequency of formation of hemolytic disease in newborns from mothers with sensitization by the ABO system.

We obtained similar results when studying the level of the product of proteolysis and cytochrome $\mathrm{C}$ in serum obtained from umbilical cord blood of newborns. Thus, the concentration of TZP and TRP in the blood serum isolated from the umbilical cord of newborns from puerperas with $\mathrm{ABO}$ immunization compared with the control exceeds 45.5 and 33.7\% ( $\mathrm{P}<0.001$ and $\mathrm{P}<0.01$ ), respectively, MMM254 and MMM280 - by 52.0 and
$30.3 \%$, respectively, and the content of cytochrome C by $36.1 \%$. In connection with the obtained research results, there is a need to improve treatment measures in the antenatal period, in pregnant women with $\mathrm{ABO}$ immunization, i.e. to find a drug that affects the reduction of endogenous intoxication.

\section{References}

1. Bowman JM (1999) Hemolytic disease (Erythroblastosis fetalis) Maternal-fetal medicine $4^{\text {th }}$ edition. Philadelphia: WB Saunders pp. 736767.

2. Saveleva GM (2006) Problema rezus-sensibilizasii: sovremennie podxodi. Vestnik RGMU 51(4): 59-63.

3. Antashyan GG (2009) Primenenie enterosorbentov v kompleksnoy profilaktike i lechenii plasentarnoy nedostatochnosti u beremennix Avtoref Dis kand. med. nauk: Rostov na Donu p. 20.

4. Delaney M, Matthews D (2015) Hemolytic disease of the fetus and newborn: managing the mother, fetus, and newborn. American Society of Hematology 2015: 146-151.

5. Santavy J (2010) Hemolytic disease inthe newborn - history and prevention in the world and the czech republic. Biomed Pap Med Fac Univ Palacky Olomouc Czech Repub 154(2): 147-151. 